\title{
PENYELESAIAN MASALAH MODEL ANIMISTIS
}

\author{
Yustinus Slamet Antono* \\ Program Studi Ilmu Filsafat, Fakultas Filsafat, Unika Santo Thomas \\ Email: yustinov_ant@yahoo.com
}

\begin{abstract}
Abstrak
Pemberian hadiah merupakan fenomena yang mudah dijumpai di berbagai kebudayaan yang ada di muka bumi. Melalui cara itu relasi antar sesama manusia dipererat dan dipelihara. Praktek pemberian hadiah dalam berbagai bentuknya dan juga istilah-istilahnya kepada para pejabat ataupun yang memiliki kewenangan juga telah lama ada. Istilah yang sering digunakan untuk praktek tersebut adalah suap. Suap merupakan model penyelesaian masalahmasalah profan yaitu masalah-masalah yang terkait dengan kehidupan seharihari. Terkait dengan fenomena suap-menyuap, apakah religiositas tradisional berkontribusi dalam menyediakan model penyelesaian masalah seperti itu? Dalam artikel ini akan dibahas cara pandang masyarakat terhadap dunianya serta sikap-sikap yang diperlukan baik pada saat dalam keadaan biasa-biasa saja maupun ketika berhadapan dengan masalah-masalah kehidupan serta cara penyelesiannya. Melalui pendapat para ahli Jawa, masyarakat Jawa akan dijadikan sebagai bahan analisa untuk menjawab pertanyaan di atas.
\end{abstract}

Kata-kata Kunci: Animisme, yang sakral, ritual, sesaji, slametan.

\section{Animisme}

Terdapat banyak orang di luar etnis Jawa yang mencurahkan perhatiannya pada kehidupan orang Jawa. Di antara mereka memusatkan perhatiannya pada religiositas orang Jawa dalam kehidupan sehari-hari. Buah pikiran mereka sebagaimana dituliskan dalam buku-buku sering digunakan oleh ahli lainnya bila hendak meneliti atau mendalami religiositas Jawa dan efeknya pada bidang kehidupan yang lain. Di antara ahli Jawa yang bukan orang Jawa tersebut antara lain: Clifford

*Yustinus Slamet Antono, Doktor dalam bidang Ilmu Sosiologi; lulusan Universitas Indonesia, Jakarta; dosen tetap pada Fakultas Filsafat Unika St. Thomas, Sumatera Utara. 
Geertz (antropolog asal Amerika serikat), Niels Mulder (sosiolog asal Belanda) dan Franz Magnis Suseno (Filsuf asal Jerman). Terkait dengan religiositas orang Jawa, mereka memiliki pemahaman yang sama dalam membahas tentang "agama asli Jawa". Mereka memandang bahwa animisme merupakan dasar dari berbagai ekspresi religiositas Jawa. Pemahaman itu bukan hanya didapat dari penelusuran literatur yang ditulis oleh pengarang-pengarang sebelumnya, tetapi juga didapat dari riset dan pengalaman tinggal dan hidup bersama dengan orang Jawa. Pengalaman tinggal bersama orang Jawa itu kiranya penting disinggung karena pengalaman itu terjadi pada masa beberapa tahun setelah Indonesia merdeka. Artinya, pada masa setelah Indonesia merdeka di mana terdapat lima (sekarang enam) agama yang secara resmi diakui oleh pemerintah, dalam kehidupan sehari-hari religiositas yang memiliki dasar animistis itu masih menunjukkan eksistensinya.

Dari apa yang mereka tuliskan, secara ringkas bisa dikatakan bahwa dalam religiositas Jawa terdapat semacam lapisan-lapisan keyakinan yang menyatu dalam praktek hidup sehari-hari. Lapisanlapisan itu sendiri masih bisa ditelusuri dari mana asal-usulnya. Jika lapisan-lapisan yang berasal dari agama-agama besar (yang diakui oleh pemerintah Indonesia) itu dilepaskan, maka bisa diandaikan bahwa sisa lapisan lainnya adalah religiositas asli Jawa, yaitu berbagai praktek keagamaan animistis.

Sebenarnya praktek keagamaan animistis bisa dijumpai di berbagai belahan dunia ini, dan atas alasan itulah banyak ahli khususnya sosiolog dan antropolog tertarik untuk membahas seluk-beluk dunia animisme. Dalam wacana akedemis, tokoh Edward B. Tylor (18321917) sering dijadikan sebagai acuan dalam perbincangan tentang animisme karena ia sebagai tokoh yang mengilhami munculnya ide-ide baru sebagai antitesis. Tylor sendiri berspekulasi ketika ia berpendapat bahwa animisme merupakan tingkat yang tertua dalam evolusi religi. Ia berpendapat bahwa makhluk halus yang tidak dapat ditangkap oleh pancaindera manusia, dapat melakukan hal-hal yang tak dapat dilakukan manusia, menghuni alam sekeliling tempat tinggal manusia. Mereka dianggap sangat penting sehingga menjadi obyek penghormatan dan 
penyembahannya melalui berbagai ritual, doa, sajian, korban dan lain sebagainya. Tingkatan berikutnya munurutnya adalah kepercayaan pada kekuatan alam seperti aliran sungai, air terjun, gunung yang meletus, gempa bumi, berbagai jenis tetumbuhan dan lain sebagainya. Semuanya disebabkan oleh kekuatan alam yang oleh manusia dipersonifikasikan sebagai makhluk-makhluk yang memiliki kepribadian, kehendak dan akal. Makhluk-makhluk itu kemudian "menjelma" menjadi dewa-dewa. Tingkatan evolusi berikutnya berkembang seiring dengan berkembangnya susunan kenegaraan dalam masyarakat di mana kekuasaan dalam masyarakat tersusun secara hierarkis. Mereka yang dianggap sebagai dewa tersebut juga tersusun secara hierarkis (Koentjaraningrat, 1998: 196).

Emile Durkheim menolak anggapan Tylor bahwa animisme merupakan bentuk paling awal dari evolusi agama. Tetapi Durkheim tidak menolak bahwa dalam masyarakat terdapat keyakinan animistis seperti itu. Terkait dengan animisme Durkheim mengatakan:

The other has spiritual beings as its object, spirits, soul, geniuses, demons, divinities properly so-called, animated and conscious agent like man, but distinguish from him, nevertheless, by the nature of their powers and specially by the peculiar characteristic that they do not affect the senses in the same way: ordinaly they are not visible to human eyes. This religions of spirit is called animsm (Emile Durkheim, 1965: 65).

Secara konseptual terdapat beberapa ide penting pada pembicaraan para ahli tentang animisme itu yaitu keyakinan akan adanya kekuatan di balik fenomena alam, kekuatan-kekuatan yang dipersonifikasikan sebagai roh, dewa-dewa dan ritual-ritual yang terkait dengan keyakinanya itu.

Terkait dengan pandangan berbagai ahli tentang animisme, Koentjaraningrat mengatakan bahwa teori-teori terpenting perilaku yang bersifat religi meliputi: manusia mulai sadar akan adanya konsep roh, manusia mengakui adanya berbagai gejala yang tak dapat dijelaskan dengan akal, keinginan manusia untuk menghadapi berbagai krisis yang 
senantiasa dialami dalam daur hidupnya, kejadian-kejadian luar biasa yang dialami manusia di alam sekelilingnya, adanya getaran (yaitu emosi) berupa rasa kesatuan yang timbul dalam jiwa manusia sebagai warga dari masyarakat, manusia menerima suatu firman Tuhan (Koentjaraningrat, 1997: 194-195).

Di atas telah sedikit disinggung bahwa jika lapisan religiositas Jawa sekarang ini dikurangi unsur-unsur religiositas yang berasal dari luar Jawa maka lapisan yang tersisa adalah religiositas asli Jawa yaitu religiositas animistis. Informasi tertua (yang penulis miliki) terkait dengan praktek keagamaan animistis orang Jawa ditulis oleh seorang ahli Javanologi Belanda bernama H.A. van Hien. Tulisan tersebut agaknya merupakan hasil penelitian yang berlangsung pada tahun 1920-an. Walaupun ia tidak terkenal, ia memiliki sekurang-kurangnya tiga buku berbahasa Belanda yang terbit pada tahun 1935 (Capt. R.P. Suyono, 2009: 274). Ia lebih banyak menyajikan semacam panorama praktek keagamaan orang Jawa yang terjadi pada masa itu. Capt. R.P. Suyono sebagai orang yang memiliki kegemaran mengoleksi buku-buku kuno dalam bahasa Belanda menyusun salah satu karya H.A. van Hien tersebut dari buku berjudul De Javaansche Geestenwereld. 1 ste deed De Geschiedenis der Godsdiensten op Java ke dalam bahasa Indonesia. Buku tersebut diberi judul Dunia Mistik Orang Jawa Roh, Ritual, Benda Magis yang terbit pada tahun 2009.

Seperti telah disinggung di atas arti penting isi buku tersebut adalah terdapatnya berbagai informasi tentang religiositas Jawa pada masa lalu yang pada masa sekarang masih dipraktekkan oleh sebagian besar orang Jawa walaupun secara faktual mereka telah memeluk agama yang diakui oleh pemerintah. Informasi-informasi penting itu terutama mengenai obyek sakral (the Sacred things) dan berbagai sikap yang menyertainya sebagai implikasi dari keyakinan terhadap eksistensi obyek tersebut. Untuk selanjutnya di belakang nanti beberapa hal penting tadi akan dihadirkan dalam bentuk kutipan-kutipan atau sebagai rujukanrujukan pada pembahasan selanjutnya. 


\section{Refleksi Beberapa Ahli}

Dalam studinya tentang masyarakat Jawa Clifford Geertz sampai pada kesimpulan bahwa tradisi religius Jawa, khususnya dari kaum petani, merupakan sebuah campuran unsur-unsur India, Islam, dan unsurunsur pribumi Asia Tenggara. Religiositas itu ditampakkan dalam bentuk pelaksanaan ritual-ritual tradisional yang menurut Geertz merupakan sebuah hasil sinkretisme ${ }^{1}$ yang selaras dari mitos dan ritus yang di dalamnya dewa-dewi Hindu, nabi-nabi Muslim dan para santo, dan rohroh dan makhluk-makhluk halus setempat semua mendapat tempat yang layak (Clifford Geertz, 1992: 76).

Kepercayaan seperti itulah agaknya yang menjadi dasar bagi sementara ahli untuk mengatakan bahwa pandangan dunia orang Jawa pada dasarnya animistis seperti tampak pada tulisan berikut:

Pandangan tentang kesatuan hakiki dari apa saja yang ada terbawa juga ke dalam dunia materiil, pandangan dunia orang Jawa pada dasarnya animistis. Benda-benda dipengaruhi oleh spiritualitas pemiliknya atau pembuatnya, dan dapat memuat kekuatan mereka. Kejadian-kejadian alamiah - seperti kekeringan, letusan gunung berapi, atau serangan-serangan hama - memiliki makna adikodrati dan berlaku sebagai tanda-tanda yang berasal dari gerak-gerik kosmos. Hampir setiap rumah tangga Jawa memiliki pusaka yang harus dihormati dan dimuliakan dengan upacara. Benda-benda ini memiliki kekuatan gaib yang dapat dipakai untuk tujuan-tujuan mistik, magis, maupun untuk melindungi diri. Begitu juga, makam para leluhur, para raja, dan para guru mistik dianggap sebagai tempat-tempat keramat yang dipakai sebagai tempat-tempat bermeditasi untuk mencapai pengetahuan mistik atau untuk memperoleh kekuatan-kekuatan spiritual. Hubungan antara dunia dan alam adiduniawi begitu eratnya sehingga tak

\footnotetext{
1 Dalam perbincangan tentang kemurnian agama konsep sinkretisme bernuansa negatif. Sinkretisme merujuk pada upaya pencampuradukan antara agama yang satu dengan agamaagama yang lain sehingga menghasilkan semacam agama baru. Jika disederhanakan kurang lebih rumusannya adalah $\mathrm{A}+\mathrm{B}=\mathrm{C}$, di mana $\mathrm{A}$ adalah suatu agama tertentu dan $\mathrm{B}$ adalah agama yang lainnya. $\mathrm{C}$ adalah hasil pencampuran antara $\mathrm{A}$ dan $\mathrm{B}$.
} 
mungkinlah membuat garis pemisah di antara keduanya; keduanya berpartisipasi dalam kesatuan yang ada, dan bendabenda sehari-hari dapat memuat pertanda-pertanda dan kekuatankekuatan proses kosmos yang meliputi segala-galanya. (Niels Mulder, 1984: 18).

Pandangan seperti itu akan diulang kembali oleh ahli lain jika ia mengupas tentang pandangan hidup orang Jawa (Franz Magnis Suseno, 1985). Keyakinan orang Jawa seperti yang dilukiskan oleh Geertz, Mulder dan Suseno sebenarnya masih bisa ditemukan dengan sangat mudah pada saat ini. Rahmat Subagya (1981), memandang animisme sebagai setiap kepercayaan akan adanya unsur rohani atau jiwa (anima) pada unsur jasmani. Dalam arti khusus ia memandang bahwa animisme adalah kepercayaan akan roh-roh halus yang berdiri lepas dari manusia namun kadang-kadang terlibat dalam kehidupan manusia. Keyakinan seperti itu bukan bagian dari masa lalu, tetapi bagi sebagian orang Jawa keyakinan seperti itu memang bagian dari kepercayaan generasi terdahulu tetapi sekaligus merupakan bagian dari keyakinan (informal) generasi masa sekarang.

Bagi orang Jawa alam empiris berhubungan erat dengan alam gaib. Pengalaman-pengalaman empiris orang Jawa tidak pernah empiris semata-mata. Di beberapa tempat penelitian, saya menyempatkan diri untuk bertanya tentang makhluk-makhluk halus atau kekuatan-kekuatan yang luar biasa baik yang terdapat di lokasi-lokasi gua Maria maupun tempat lain. Hal itu saya maksudkan untuk menguji apakah keyakinan seperti itu masih bertahan hingga sekarang. Pada umumnya mereka memberikan jawaban yang mengesankan bahwa memang di beberapa tempat terdapat kekuatan-kekuatan yang luar biasa atau terdapat makhluk supranatural yang tinggal di dalamnya (Wawancara, 28-04-2011). Alam metempiris yang angker dan mengasyikkan menjadi isi pengalaman itu sendiri. Alam empiris selalu sudah diresapi oleh alam gaib (Franz Magnis Suseno, 1985: 86).

Ritual slametan tidak terlepas dari cara pandang orang Jawa terhadap hal-hal di atas. Geertz melihat bahwa slametan merupakan ritual 
inti sinkretisme. Ritual itu menghasilkan dua hal yaitu roh-roh ditenangkan dan solidaritas ketetanggaan diperkuat (Clifford Geertz, 1982: 77). Dalam perkembangan seperti akan kita lihat di belakang, berbagai bentuk ritual tradisional mengalami pergeseran atau hilang sama sekali dari peredaran dalam arti tidak lagi memperoleh tempat untuk bisa diekspresikan. Pergeseran itu tentu saja juga terkait dengan pemahaman terhadap lingkungan alam yang bergeser entah karena masuknya ilmu pengetahuan atau tergantikan oleh paham baru yang datang dari agama baru yang masuk ke Jawa pada abad-abad belakangan. Sudah menjadi pengetahuan umum bahwa agama Islam dianut oleh sebagian besar masyarakat Jawa pada masa akhir Majapahit. Sementara itu agama Katolik dan Protestan masuk pada akhir abad ke-19.

Fenomena keagamaan lain yang tidak pernah luput dari perhatian para pemerhati kebudayaan Jawa adalah keberadaan berbagai aliran kebatinan. Dalam pandangan para ahli itu, pada aliran-aliran kebatinanlah ajaran-ajaran yang terkait dengan bagaimana seharusnya orang bertindak diajarkan secara eksplisit, di samping tentu saja ajaran-ajaran tentang bagaimana harus bertindak dalam kehidupan juga diajarkan pada agamaagama besar. Para ahli itu mencari prinsip-prinsip dasar yang ada pada aliran-aliran kebatinan untuk kemudian dihubungkan dengan bidang keilmuannya masing-masing hingga menghasilkan tulisan dengan judul sesuai keahlian ilmuwan yang bersangkutan kemudian ditambahkan kata Jawa sebagai subyek studinya. Walaupun berpijak pada studi tentang aliran-aliran kebatinan, tulisan yang dihasilkan memberikan keterangan yang memuaskan mengenai beberapa segi kehidupan orang Jawa pada umumnya. Sebabnya adalah hal-hal yang ditekankan oleh penganut aliran kebatinan sebenarnya juga ditekankan oleh orang Jawa yang tidak tergabung dalam aliran kebatinan manapun. Sebagai contoh, himbauan untuk sepi ing pamrih dan rame ing gawe, yang kurang lebih sama dengan upaya pengekangan diri demi kepentingan orang banyak ditekankan juga oleh masyarakat umum bahkan termasuk mereka yang bukan Jawa. Intisari dari pandangan para ahli tentang masyarakat Jawa adalah untuk mengerti tindakan orang Jawa orang harus mengerti cara pandang orang Jawa terhadap dunianya. Mengetahui cara pandang orang Jawa akan menguntungkan bagi peneliti yang penelitiannya berkaitan 
dengan kebudayaan Jawa dan tidak melibatkan hal itu akan menjadi kekurangan yang tidak bisa dipandang ringan.

\section{Penyelesaian Masalah Model Animistis}

Banyak pengarang yang berpandangan bahwa ilmu pengetahuan yang ada sekarang ini berkembang karena adanya agama. Atau setidaknya terdapat banyak pandangan yang meyakini bahwa agama berkontribusi sangat besar pada berkembangnya ilmu pengetahuan. Dari manapun asal mula ilmu pengetahuan, yang jelas salah satu fungsi yang disandangnya adalah melayani manusia untuk menyelesaikan masalah. Saya ingin sedikit membicarakan masalah ini dengan mengangkat kembali pandangan beberapa ahli kebudayaan Jawa. Seperti telah dikemukakan berkali-kali di depan, kepercayaan Jawa itu animistis dan sinkretis. Alasanya antara lain orang Jawa percaya pada berbagai kekuatan supranatural yang dipersonifikasikan sebagai roh-roh. Bukan hanya itu, orang Jawa juga percaya bahwa mereka (roh-roh) memiliki potensi mengganggu kehidupan manusia. Bukan hanya itu, orang Jawa juga harus berdamai dengan berbagai kekuatan supranatural yang ada di sekelilingnya. Dan, ... karena itu semua, sederetan ritual harus dilakukan. Itulah isi pandangan dunia Jawa, begitu kata para ahli Jawa tersebut. Mengandaikan bahwa cara pandang seperti itu benar, maka saya tertarik untuk mengulas masalah cara penyelesaian masalah ala Jawa yang bermakna ala animistis.

Gagasan Alfred Schutz tentang stok pengetahuan agaknya cocok untuk mengawali diskusi ini. Dengan mengedepankan aspek stok pengetahuan, maka dengan sendirinya diandaikan terdapat suatu proses bagaimana pengetahuan itu masuk dalam diri individu. Schutz berpandangan bahwa stok pengetahuan itu antara lain berguna untuk memberi referensi atau orientasi bagi seseorang sebelum ia melakukan sesuatu. Stok pengetahuan itu sendiri diperoleh melalui proses sosialisasi dalam dunia sosial dan budaya di mana ia hidup. Pandangan itu setidaknya memberi sedikit penjelasan mengapa pandangan dunia Jawa dapat bertahan hingga hari ini. 
Sukses atau tidaknya seseorang dalam kehidupan semata-mata bukan tergantung dari kepintaran atau ketekunan dalam bekerja, tetapi juga tergantung dari apakah ia bisa berdamai dengan roh-roh yang tinggal di sekeliling mereka (Magnis Suseno 1984). Dengan kata lain, roh-roh merupakan penghalang sukses atau tidaknya seseorang dalam kehidupan. Petunjuk dari generasi sebelumnya (stok pengetahuan) untuk mengatasi seperti itu, orang harus memberikan sesaji. Sesaji juga perlu diberikan di berbagai tempat yang diyakini terdapat roh-roh apabila orang akan menyelenggarakan pesta. Melupakan hal itu ia bisa ditimpa berbagai kesulitan pada saat menyelenggarakan pesta ataupun sesudahnya. Rohroh yang berpotensi mengganggu harus ditenangkan dengan sesaji. Itulah prosedur tradisional animistis yang diwariskan oleh generasi terdahulu. Persoalan yang ada di dunia empirik, penyebabnya ditemukan di dunia metempirik dan karena itu prosedur penyelesiannya adalah melalui ritual. Karena itulah bahasa yang dimengerti oleh roh-roh itu. Melakukan semua itu dengan "benar" manusia boleh menikmati hasilnya yaitu keadaan slamet, tidak ada gangguan dan dapat meneruskan hidup dengan aman.

Model sebagai model agaknya tetap bertahan hingga sekarang. Dalam hal apa? Model sesaji itu juga dipergunakan orang untuk menyelesaikan kesulitan-kesulitan riil yang disebabkan oleh kondisi sosial yang ada. Bagaimana model itu digunakan? Ketika orang memiliki masalah untuk usaha tertentu misalnya, ia akan mengidentifikasi masalah sebelum menyelesaikannya. Katakanlah masalahnya ternyata perijinan untuk membuat usaha tidak bisa turun jika ia tidak membayar sekian rupiah (tidak seharusnya). Yang ia lakukan ternyata kemudian adalah memberikan uang kepada petugas yang bersangkutan. Ternyata setelah ia memberi "sesaji" kepada petugas itu ijin keluar dengan sangat cepat. Model penyelesaian inilah yang saya beri nama penyelesaian masalah model animistis. Skema di bawah ini akan mempermudah melihat kesamaan dalam menyelesaikan masalah. 


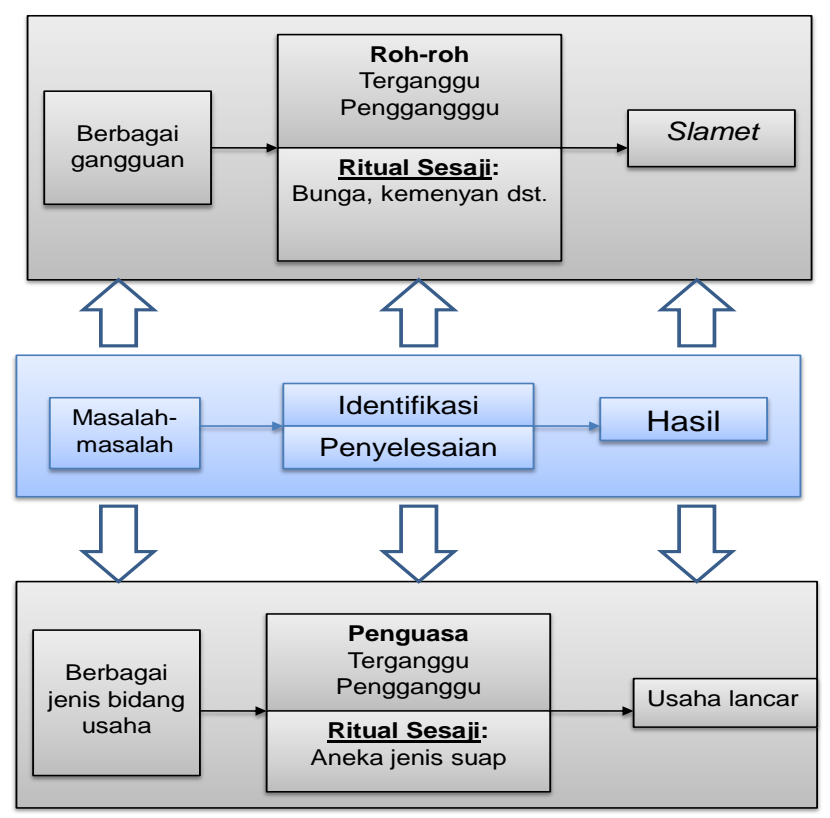

Skema Model Penyelesaian Masalah

Dalam kasus di atas terdapat sifat-sifat yang sama antara penguasa dan roh-roh. Mereka sama-sama suka menerima sesaji. Perbedaannya terletak pada jenis sesajian yang diberikan. Sama seperti dalam pemahaman animistis bahwa roh-roh mempunyai potensi mengganggu, penguasa atau pejabat yang berwewenang juga memiliki potensi mengganggu caranya dengan menyalahgunakan kewenangan dan juga kekuasanaannya. Pada saat yang lain, penguasa juga memiliki kesamaan dengan roh-roh, yaitu mudah terusik atau terganggu oleh usaha-usa tertentu dari sementara orang. Jika cara berpikir seperti itu dibenarkan, maka agaknya penyelesaian masalah model animistis itulah yang digunakan kebanyakan orang dalam menyelesaikan masalahmasalah praktis kehidupan di mana urusan dengan para penguasa akan lancar jika para penguasa itu telah menerima "sesaji”. Saya berpandangan bahwa praktek "sesaji” kepada penguasa seperti itu juga menjadi stok pengetahuan yang ada pada masyarakat dalam menyelesaikan masalah. Dalam perspektif Berger, dijadikannya prosedur animistis dalam penyelesaian masalah sebagai stok pengetahuan terjadi melalui proses 
berikut. Dalam kehidupan sehari-hari, tipifikasi diberikan pada semua pengalaman dalam dimensi waktu dan ruang. Individu-individu diberi tipifikasi, perilaku-perilaku terpola ditipifikasi. Lewat proses tipifikasi kemudian terbentuk institusi. Tipifikasi dan institusi ini menjadikan realitas sosial sebagai sesuatu yang obyektif. Institusionalisasi, kata Berger, terjadi kapanpun ada tipifikasi timbal-balik terhadap tindakantindakan yang sudah menjadi kebiasaan.

\section{Penutup}

Pembahasan di atas merupakan upaya untuk menghubungkan religiositas tradisional dengan fenomena suap yang terjadi baik pada masa lalu maupun dewasa ini. Walaupun bukan merupakan hubungan sebab akibat, ritual tradisional yang merupakan bagian dari religiositas tradisional telah menyediakan model yang kurang lebih memiliki kesamaan dengan model penyelesaian masalah pada kehidupan konkrit dewasa ini. Hal itu tidak berarti bahwa tidak terdapat orang yang berpegang teguh pada nilai-nilai religius tradisional yang tetap menyelesaikan masalah dengan prosedur formal terutama jika mereka memiliki moralitas yang tinggi di mana setiap tindakan dipertimbangkan dengan baik dalam hatinya.

\section{DAFTAR PUSTAKA}

Berger, Peter, L., Langit Suci, Agama sebagai Realitas Sosial, Jakarta: LP3ES, 1991.

Berger, Peter, L., dan Hansfried Kellner, Sosiologi Ditafsirkan Kembali : Esei tentang Metode dan Bidang Kerja, Jakarta : LP3ES, 1985.

Berger, Peter, L. and Luckmann, The Social Construction of Reality, Garden City: Doubleday \&Company, Inc., 1966. 
Durkheim, Emile, The Elementary Forms of the Religious Life, New York: The Free Press, 1965.

Endraswara, Suwardi, Kebatinan Jawa dan Jagad Mistik Kejawen, Yogyakarta: Lembu Jawa: 2011.

Geertz, Clifford, Abangan, Santri, Priyayi dalam Masyarakat Jawa, Jakarta: PT Dunia Pustaka Jaya, 1983.

, Kebudayaan \& Agama, Yogyakarta: Kanisius, 1992.

__ Islam yang Saya Amati, Perkembangan di Maroko dan Indonesia, Jakarta: Yayasan Ilmu-ilmu Sosial, 1982. 